\title{
Brain natriuretic peptide: identification of a second natriuretic peptide in human aqueous humour
}

Joel Salzmann, Daniel Flitcroft, Catey Bunce, David Gordon, Richard Wormald, Clive Migdal

\begin{abstract}
Aims/background-To measure aqueous humour levels of brain natriuretic peptide (BNP) and atrial natriuretic peptide (ANP) in humans. To compare peptide levels in glaucomatous and control eyes to test the hypothesis that these peptides are increased in glaucoma. BNP and ANP are cyclic endopeptides whose principal biological effects are natriuresis and vasodilatation. Experimental glaucoma in animal models results in elevated aqueous ANP. Intravenous ANP administration in both animals and humans causes lowering of intraocular pressure (IOP). There are equivocal data to support a role for ANP in IOP regulation in human eyes. There are as yet no published data on BNP in human aqueous humour.
\end{abstract}

Method-This was a case-control study. Cases were primary open angle, pseudoexfoliation, and mixed mechanism glaucoma eyes undergoing trabeculectomy. Controls were cataract extraction eyes. There were 47 trabeculectomy eyes (44 patients) and 47 cataract extraction eyes (46 patients) matched for age, sex, race, systemic medications, and type of anaesthetic. 100-200 $\mu \mathrm{l}$ of aqueous humour were aspirated by paracentesis as the first step in the surgical procedure. Peptide levels were later measured by radioimmunoassay.

Results-The presence of BNP and ANP in human aqueous humour was confirmed. BNP was present in higher concentrations than ANP. BNP levels tended to be greater in control eyes-glaucoma median 56.5 (range $0-3526.5$ ) $\mathrm{pg} / \mathrm{ml}$ versus control median 65.16 (range 0-1788) $\mathrm{pg} / \mathrm{ml}$ (Wilcoxon signed rank test $p=0.78)$. ANP levels tended to be greater in glaucoma eyes than in controls: glaucoma median 3 (range 0-68.5) $\mathrm{pg} / \mathrm{ml}$ versus control median 0 (range 0-60) $\mathrm{pg} / \mathrm{ml}$ (Wilcoxon signed rank test $\mathrm{p}=0.82)$. ANP and BNP were log linearly related in both groups ( $r$ glaucoma group $=0.961, r$ control group $=0.894)$. Conclusion-This is the first report of BNP and ANP in human aqueous humour. Peptide levels did not differ significantly between glaucoma and cataract extraction eyes. A linear relation between $\log$ BNP and ANP was found. Further studies are required to clarify the role of these peptides in aqueous humour production and IOP regulation.

(Br f Ophthalmol 1998;82:830-834)

The natriuretic peptides are a class of cyclic peptides which play an important role in sodium homeostasis. ${ }^{1}$ Three peptides in this class have been identified to date-atrial natriuretic peptide (ANP), brain natriuretic peptide (BNP), and C peptide. These compounds have been extensively studied in hypertension and cardiac failure where their diagnostic and therapeutic potentials are considerable. ${ }^{2}$ Analogies between hypertension (systemic volume overload) and glaucoma (raised intraocular pressure (IOP)) have led to the investigation of ANP as an IOP reducing agent.

The role of ANP in the regulation of IOP and aqueous humour production is ill understood. $^{3}$ Experimental data in animals suggest that intraocular ANP increases as IOP elevates. ${ }^{4}$ Conversely, intravenous, ${ }^{5}$ intracameral, $^{67}$ or intravitreal ${ }^{8}$ ANP administration results in decreased IOP. Furthermore, natriuretic peptide receptors have been identified on the ciliary epithelium ${ }^{9}$ and corneal endothelium. ${ }^{10}$ Pilot studies in humans have suggested an IOP lowering effect of both ANP administration and inhibition of ANP degradation by the non-specific neutral endopeptidase inhibitor candoxatril. ${ }^{112} \mathrm{BNP}$, for its part, plays an important role in tandem with ANP in systemic volume regulation, but there have been no reports to date on BNP in human aqueous humour. Ophthalmic natriuretic peptide data derive from animal research and there is a paucity of human data. We therefore measured BNP and ANP levels in peroperative aqueous humour, and compared eyes with chronic glaucoma with age matched normals undergoing cataract extraction.

\section{Methods}

SUBJECTS

A case-control study was set up and ethical approval obtained from the local hospital ethics committee. "Cases" were eyes with primary open angle, pseudoexfoliative or chronic narrow angle glaucoma with progressive field loss or inadequate IOP control. Normal tension, inflammatory, and rubeotic glaucoma cases were excluded. Cataract extraction eyes were used as controls.

Exclusion criteria included use of topical steroids, a history of ocular inflammation, 
Table 1 Glaucoma treatment regimens for the 47 "case" eyes

\begin{tabular}{lll}
\hline Drugs & $\begin{array}{l}\text { No of eyes } \\
(n=47)\end{array}$ & $\%$ \\
\hline$\beta$ blocker & 11 & 23 \\
$\beta$ blocker + pilocarpine & 29 & 62 \\
$\beta$ blocker + dipivefrin & 1 & 2 \\
$\beta$ blocker + acetazolamide & 1 & 2 \\
No medications & 5 & 11 \\
\hline
\end{tabular}

closed angle glaucoma, or a history of intraocular surgery. Argon laser trabeculoplasty (ALT) or YAG laser iridotomy more than 6 months before entry were allowable. Systemic exclusion criteria were untreated hypertension, renal failure, and systemic steroid therapy. Eyes were matched for age, sex, race, type of anaesthetic, and class of systemic medication.

\section{STATISTICAL ANALYSIS}

Based on an estimated standard deviation (SD) of ANP values obtained in a previous pilot study, ${ }^{13}$ the study would have a $90 \%$ chance of detecting as statistically significant at the $5 \%$ level a true difference between cases and controls of $20 \mathrm{pg} / \mathrm{ml}$, if 41 eyes were recruited per group - that is, 82 eyes in total.

Cases and controls were checked for efficiency of matching by comparing the two groups. The paired $t$ test was used to compare baseline IOP and age between the two groups. Because of the skewed distribution of natriuretic peptide values which were obtained, aqueous BNP and ANP measurements were compared using the Wilcoxon signed rank test, the non-parametric equivalent of the paired $t$ test. Scatter plots of aqueous proteins against aqueous peptides were studied to assess their relation. The correlation coefficient was computed to assess linear association between aqueous ANP and BNP in each group after log transformation of non-zero BNP data.

\section{CLINICAL PROCEDURE}

Informed consent was obtained from all patients. A baseline IOP was recorded 2 weeks preoperatively. Local anaesthesia was given by peribulbar or retrobulbar injection of up to 10 $\mathrm{ml}$ of lignocaine and/or bupivacaine with hyaluronidase. Fifteen surgeons participated in aqueous humour harvesting. Aqueous taps were performed by paracentesis with a 25 gauge needle mounted on an insulin syringe at the start of surgery immediately before anterior chamber opening. In trabeculectomy cases, this was performed after fashioning of the partial thickness scleral flap. Samples visibly contaminated with blood were discarded immediately.

Table 2 Characteristics of the study population

\begin{tabular}{lll}
\hline & Glaucoma cases (47 eyes) & Matched controls (47 eyes) \\
\hline Median age & 72 years (range 36-91) & 76 years (range 41-86) \\
Sex & M: 27 F: 20 & M: 27 F: 20 \\
Race & Asian: 4; white: 35; Afro-Caribbean: 8 & Asian: 4; white: 35; Afro-Caribbean: 8 \\
Anaesthetic & LA: 29; GA:18 & LA: 29; GA:18 \\
Mean IOP & 23 mm Hg & 16 mm Hg \\
(SD) & $(5.39)$ & $(2.74)$ \\
\hline
\end{tabular}

$\mathrm{LA}=$ local anaesthetic; $\mathrm{GA}=$ general anaesthetic.
ASSAY METHODOLOGY

Aqueous humour was immediately transferred to an Eppendorf tube containing $50 \mu \mathrm{l}$ of wetting agent $0.1 \%$ Triton $\mathrm{X}$ in phosphate buffer $0.1 \mathrm{M}$ and frozen at $-70^{\circ} \mathrm{C}$ to await radioimmunoassay (RIA), the methodology of which was adapted from plasma natriuretic peptide assays. ${ }^{14-16}$ Samples were later thawed on ice and a $50 \mu \mathrm{l}$ aliquot assayed for total protein using the Biuret method on a Roche Cobas Mira autoanalyser with Sigma Total protein reagent. Results were expressed in $\mathrm{pg} / \mathrm{ml}$. Aqueous humour total protein dosage was performed so that BNP and ANP levels could also be expressed as a fraction of total protein (pg peptide/mg protein). A measured volume of each aqueous humour sample was then transferred to a $4.5 \mathrm{ml}$ polypropylene tube on ice and $500 \mu 11 \mathrm{M}$ acetic acid/25 $\mathrm{mM}$ hydrochloric acid in deionised water was added to each tube. The tubes were vortex mixed and centrifuged at $2000 \mathrm{~g}$ at $4^{\circ} \mathrm{C}$ for 60 minutes. Each supernatant was decanted and dried in a Savant SC200 SpeedVac drier. RIA was performed using Peninsula kits (product numbers RIK 8798 (alpha-ANP 1-28) and RIK 9086 (BNP 32 human), Peninsula Laboratories, Belmont, CA, USA). The assays were performed according to manufacturers' instructions with one modification: $50 \mu$ instead of $100 \mu \mathrm{l}$ of rabbit anti-ANP/BNP antibody were used per tube as this increased assay sensitivity.

Investigators performing the peptide radioimmunoassays were masked to the casecontrol status of the samples.

\section{Results}

Aqueous taps were performed on 118 eyes; 12 samples had inadequate volumes and were discarded; 106 samples were assayed; 100 eyes were then matched into pairs. Eight samples (six glaucoma, two controls) were from four patients undergoing bilateral consecutive surgery in separate episodes. Following strict application of exclusion criteria 47 eye pairs remained for analysis. In the glaucoma group three eyes $(6.5 \%)$ had pseudoexfoliative glaucoma, three eyes $(6.5 \%)$ had chronic narrow angle glaucoma, and 41 eyes (87\%) had primary open angle glaucoma. Glaucoma treatment regimens are listed in Table 1.

Table 2 shows that the groups were identical with respect to race, sex, and type of anaesthetic. Study eyes were mostly from white patients $(74.5 \%)$, more often from males than females $(58 \% v 42 \%)$, and from eyes anaesthetised under local rather than general anaesthesia $(62 \% v 38 \%)$. There was no significant group difference between cases and controls for age. As expected, IOP was statistically significantly greater in cases than controls ( $p<0.0001)$, mean IOP difference $7.46 \mathrm{~mm} \mathrm{Hg}, 95 \%$ confidence interval $(5.7,9.1)$.

All samples were assayed in duplicate to enhance validity of results and the intratest variability was less than $10 \%$ as measured by the coefficient of variation.

Table 3 shows aqueous peptides and aqueous protein levels. Results suggest that ANP tended to be slightly greater in glaucomatous 
Table 3 Aqueous natriuretic peptides and proteins in the study population, by case-control status

\begin{tabular}{|c|c|c|c|c|c|c|c|c|}
\hline & & \multicolumn{3}{|c|}{ Glaucoma cases ( 47 eyes) } & \multicolumn{3}{|c|}{ Matched controls (47 eyes) } & \multirow{2}{*}{$\begin{array}{l}\text { Wilcoxon } \\
\text { SRT }\end{array}$} \\
\hline & & Median & $I Q$ range & Range & Median & $I Q$ range & Range & \\
\hline \multirow[t]{2}{*}{ ANP } & $\mathrm{pg} / \mathrm{ml}$ & 3.00 & $(0,6.00)$ & $(0-68.50)$ & 0 & $(0,9.00)$ & $(0-60.00)$ & $\mathrm{p}=0.82$ \\
\hline & $\mathrm{pg} / \mathrm{mg}$ protein & 4.38 & $(0,12.50)$ & $(0-266.70)$ & 0 & $(0,26.00)$ & $(0-150.00)$ & $\mathrm{p}=0.90$ \\
\hline \multirow[t]{3}{*}{ BNP } & $\mathrm{pg} / \mathrm{ml}$ & 56.50 & $(0,80.00)$ & $(0-3526.50)$ & 65.00 & $(0,96.00)$ & $(0-1788.00)$ & $\mathrm{p}=0.78$ \\
\hline & $\mathrm{pg} / \mathrm{mg}$ protein & 114.00 & $(0,195.00)$ & $(0-11755.00)$ & 162.5 & $(0,302.50)$ & $(0-4470.00)$ & $\mathrm{p}=0.33$ \\
\hline & & Mean & $S D$ & Range & Mean & $S D$ & Range & \\
\hline proteins & $\mathrm{mg} / \mathrm{ml}$ & 0.57 & 0.42 & $0-3.00$ & 0.49 & 0.25 & $0-1.8$ & \\
\hline
\end{tabular}

$\mathrm{IQ}=$ interquartile; $\mathrm{SRT}=$ signed rank test.

$\mathrm{pg} / \mathrm{mg}$ protein $=$ picograms of peptide per milligram of aqueous protein

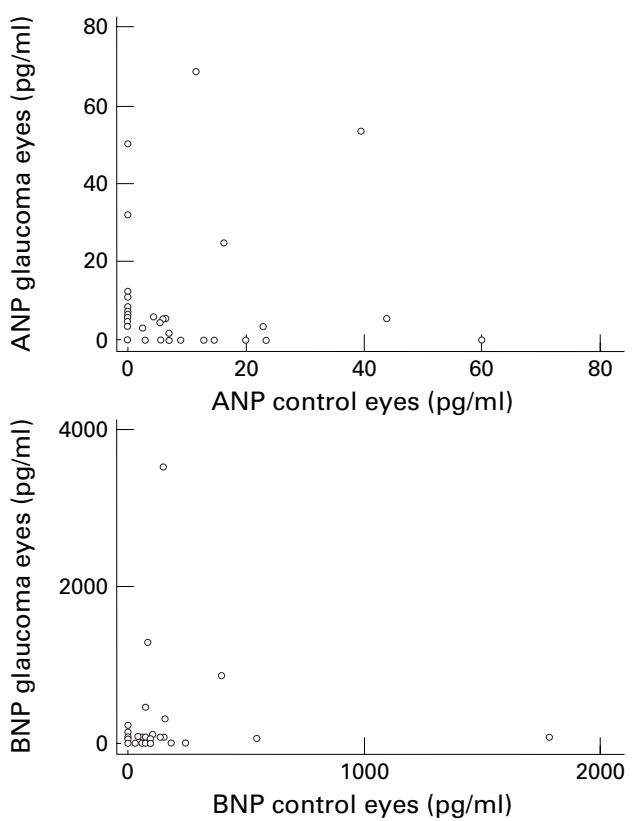

Figure 1 Paired case-control data for atrial natriuretic peptide $(A N P)$ and brain natriuretic peptide (BNP).

eyes (median $3 \mathrm{pg} / \mathrm{ml}$ ) than in control eyes (median $0 \mathrm{pg} / \mathrm{ml}$ ), but that aqueous BNP tended to be slightly greater in control eyes. This was true of both absolute and relative measures (pg aqueous peptide/ml aqueous humour and pg aqueous peptide/mg total aqueous protein) but these differences were
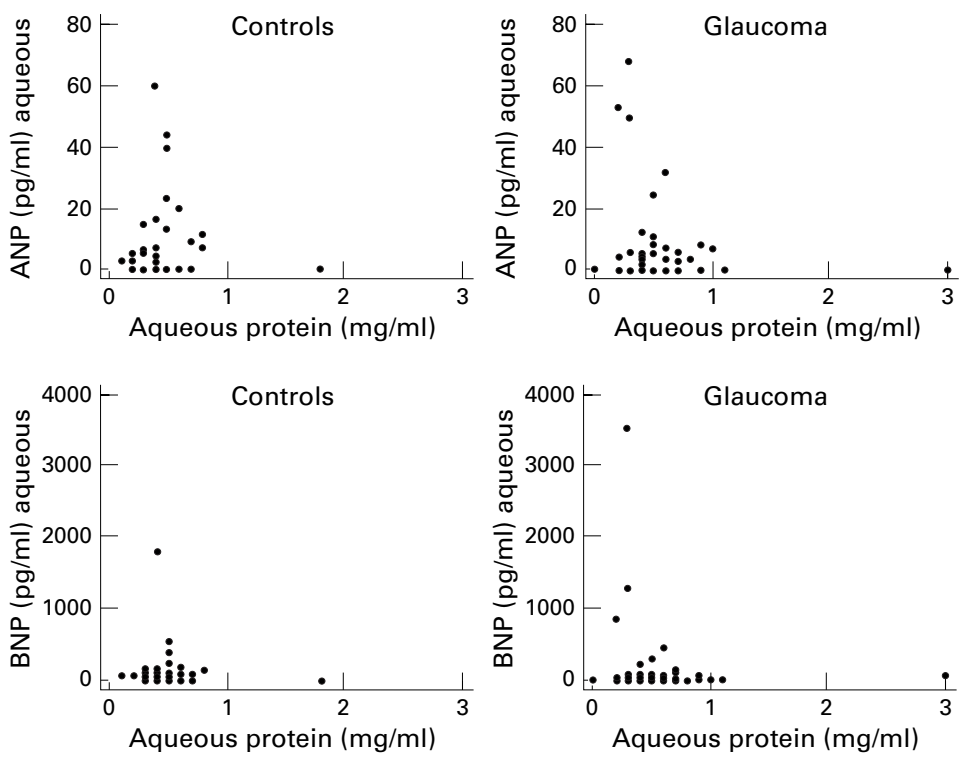

Figure 2 Scatter plots of aqueous proteins and peptides in glaucoma and cataract eyes. not statistically significant as assessed by the Wilcoxon signed rank test.

The distribution of paired case-control data for BNP and ANP is shown in Figure 1. The scatter was greatest for BNP (range 0-3526 $\mathrm{pg} / \mathrm{ml}$ in the glaucoma group).

There was no discernible correlation between glaucoma and control peptide levels. Figure 2 scatter plots reveal little association between total aqueous protein and aqueous peptides in both glaucoma and control groups. This indicates that high BNP and ANP levels were not associated with a breakdown of the blood-aqueous barrier and consequently increased aqueous protein levels.

A strong correlation was found between log BNP and ANP levels in both glaucoma and cataract eyes. Figure 3 illustrates this relation as revealed by the linearity of a scatterplot of $\log$ BNP against ANP concentrations. The correlation coefficients were 0.894 in the control group and 0.94 in the glaucoma group.

\section{Discussion}

These results suggest a linear association between ANP and log BNP (Fig 3). In the absence of cross reactivity between BNP and ANP antibodies, confirmed by the assay manufacturers, this finding suggests a link in the physiological role of these peptides. However, although closely correlated in terms of concentration, the peptides may be involved in different functions, the nature of which requires further investigation.

These results do not support the hypothesis that BNP and ANP in glaucomatous aqueous differ significantly from controls. This would suggest that these peptides do not play a primary role in IOP regulation. In the $42 / 47$ glaucoma eyes on glaucoma drugs data interpretation is limited by the impact of treatment. For ethical reasons there was no wash out period built into the study. This may have influenced results, since aqueous inflow inhibition such as occurs with timolol ${ }^{17}$ will increase aqueous protein concentration. No subgroup analysis was performed since this was not specified at the outset.

Ocular anaesthesia itself may influence aqueous peptide levels. Induction agents in adult general anaesthesia (GA) habitually cause a transient IOP reduction. ${ }^{18-20}$ In local anaesthesia (LA), particularly peribulbar blocks, ${ }^{21}{ }^{22}$ IOP increases. The ocular hypertensive effect is more marked in eyes with glaucoma. ${ }^{23} \mathrm{BNP}$ and ANP levels in our study were not significantly different in LA or GA 

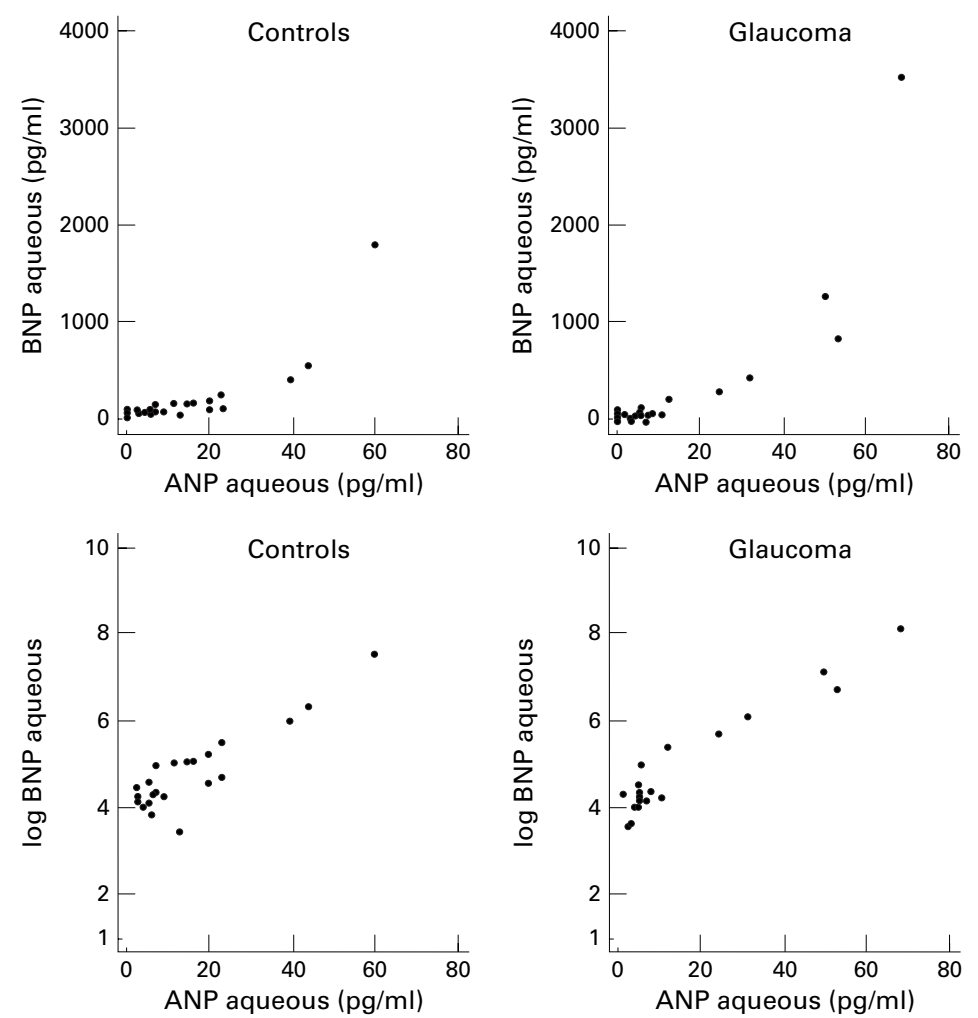

Figure 3 Relation between atrial natriuretic peptide (ANP) and brain natriuretic peptide $(B N P)$.

Table 4 Median (interquartile (IQ) range) BNP and ANP levels by type of anaesthetic and case-control status

\begin{tabular}{|c|c|c|c|c|c|}
\hline & \multicolumn{2}{|c|}{ Local anaesthetic } & \multicolumn{2}{|c|}{ General anaesthetic } & \multirow{2}{*}{$\begin{array}{l}\text { Rank sum test } \\
Z \text { statistic } \\
\text { ( } p \text { value) }\end{array}$} \\
\hline & $\begin{array}{l}\text { Median } \\
\text { (pg/ml) }\end{array}$ & $\begin{array}{l}\text { IQ range } \\
(p g / m l)\end{array}$ & $\begin{array}{l}\text { Median } \\
(p g / m l)\end{array}$ & $\underset{(p g / m l)}{I Q \text { range }}$ & \\
\hline \multicolumn{6}{|l|}{ ANP } \\
\hline Glaucoma & 0 & $(0,5.67)$ & 4.45 & $(0,6.00)$ & $1.17(\mathrm{p}=0.24)$ \\
\hline Matched controls & 0 & $(0,7.14)$ & 1.25 & $(0,11.5)$ & $0.01(\mathrm{p}=0.92)$ \\
\hline \multicolumn{6}{|l|}{ BNP } \\
\hline Glaucoma & 56 & $(0,78.00)$ & 62.84 & $(10,80.5)$ & $0.6(\mathrm{p}=0.55)$ \\
\hline Matched controls & 67.5 & $(0,95.00)$ & 63.00 & $(5,150.00)$ & $0.28(\mathrm{p}=0.78)$ \\
\hline
\end{tabular}

subgroups (Table 4). The confounding effects of anaesthesia could be avoided by performing topical anaesthesia slit lamp paracentesis, a procedure not ethically acceptable in the context of our study.

These results show a marked scatter of aqueous humour natriuretic peptide levels with a small number of outliers showing very high levels. The patients from whom these samples were taken did not appear to fit into any particular clinical subgroup, and the isolated cluster of high values remains unclear. ANP results differ from those in the animal study by Fernandez-Durango et $a l^{24}$ in which glaucoma was induced in rabbits by posterior chamber $\alpha$ chymotrypsin injection. Aqueous ANP increased over 20 times while the mean IOP doubled. There was no sign of inflammaton. The authors advanced two possible mechanisms for the ANP elevation: "volume distension" of the globe or a physiological response of the eye to high IOP. The experiment, however, simulates acute IOP elevation in humans and is a poor model for chronic glaucoma. Furthermore, since neuropeptide receptor concentra- tions vary between species, ${ }^{10}$ extrapolating from animal model results can only be tentative.

Aqueous humour protein values were similar to those previously published..$^{25}$ The lack of association between aqueous humour proteins and peptides indicates that breakdown or abnormal permeability of the blood-aqueous barrier is an unlikely explanation of the high levels of peptides in some eyes. Nathanson compared aqueous humour and plasma peptide levels and found a very low aqueous to plasma ratio. He suggested that the bloodaqueous barrier "may largely exclude atriopeptins from passing into the aqueous humour" but also that "atriopeptins are probably not actively secreted into the aqueous from uveal tissues". ${ }^{27}$ Recent evidence from the rabbit eye model provides evidence to the contrary: peptide receptor mRNA for ANP, BNP, and natriuretic peptide $\mathrm{C}$ obtained by polymerase chain reaction cDNA amplification showed a differential distribution of mRNAs in various ocular tissues; in addition, mRNA for the natriuretic peptides themselves were also differentially distributed in the eye. ${ }^{24}$ This suggests that intraocular natriuretic peptides are - at least partly-locally synthesised. Furthermore, BNP and ANP receptors have been demonstrated in human neural retina and retinal pigment epithelium ${ }^{28}$ and natriuretic peptide $\mathrm{C}$ receptors identified on the corneal endothelium, ${ }^{10}$ further suggesting a role of these peptides in the eye.

In conclusion, this is the first study to measure BNP in the human eye and to document $\mathrm{ANP}$ and BNP levels in human aqueous humour. The results do not support the hypothesis that aqueous levels of BNP or ANP are increased in glaucoma although in this respect study power was adversely affected by the wide range of peptide values. The relative contribution to aqueous humour production of locally synthesised and plasmatic natriuretic peptides, and their role in aqueous and IOP regulation remains to be clarified. Current data suggest that the natriuretic peptides and their degradative inhibitors such as candoxatril may have a role in the treatment of some forms of glaucoma.

This work was partly funded by a UK and Eire Glaucoma Society Research Award, sponsored by Alcon (UK).

The contribution of medical colleagues at the Western Eye The contribution of medical colleagues at the Western Eye
Hospital who performed aqueous sampling is gratefully acknowledged.

The authors have no proprietary interest in the compounds described in this study.

1 Mukoyama M, Nakao K, Hosoda K, et al. Brain natriuretic peptide as a novel cardiac hormone in humans-evidence for an exquisite dual natriuretic peptide system, atrial natriuretic and brain natriuretic peptide. $\mathcal{f}$ Clin Invest 1991;87:1402-12.

2 Struthers AD. Ten years of natriuretic peptide research: a new dawn for their diagnostic and therapeutic use? $B M \mathcal{F}$ 1994:308;1615-19.

3 Korenfeld MS, Becker B. Atrial natriuretic peptides. Effects on intraocular pressure, cGMP, and aqueous flow. Invest Ophthalmol Vis Sci 1989;30:2385-92.

4 Fernandez-Durango R, Triviño A, Ramirez JM, et al. Immunoreactive atrial natriuretic factor in aqueous humour: its concentration is increased with high intraocular humour: its concentration is increased with high in
pressure in rabbit eyes. Vision Res 1990;9:1305-10.

5 Tsukahara S, Sasaki T, Yamabashi S, et al. Effect of alpha-human atrial natriuretic peptides on intraocular alpha-human atrial natriuretic peptides on intraocular
pressure in normal albino rabbits. Ophthalmologica 1988; 197:104-9. 
6 Sugrue MF, Viader M-P. Synthetic atrial natriuretic factor lowers rabbit intraocular pressure. Eur f Pharmacol

7 Samuelsson-Almén $\mathrm{M}$, Nilsson SFE, Maepea O, et al. Effects of atrial natriuretic factor (ANF) on intraocular pressure and aqueous humour flow in the cynomolgus monkey. Exp Eye Res 1991;53:253-60.

8 Nathanson JA. Atriopeptin-activated guanylate cyclase in the anterior segment. Identification, localization, and effects of atriopeptins on IOP. Invest Ophthalmol Vis Sci 1987;28:1357-64.

9 Stone RA, Glembotski CC. Immunoreactive atrial natriuretic factor lowers rabbit intraocular pressure. Biochem Biophys Res Comm 1986;134:1022-8.

10 Walkenbach RJ, Guo-Sui Ye, Korenfeld MS, et al. Atrial natriuretic peptide receptors on the corneal endothelium. Invest Ophthalmol Vis Sci 1995;54:2538-43.

11 Diestelhorst M, Kriegelstein GK. The intraocular pressure response of human atrial factor in glaucoma. Int Ophthalresponse of human atria
mol 1989;13:99-101.

12 Wolfensberger TJ, Singer DRJ, Freegard T, et al. Evidence for a new role of natriuretic peptides: control of intraocular for a new role of natriuretic peptides: cont

13 Wolfensberger TJ, Salzmann J, Ationu A, et al. Natriuretic peptides in aqueous of glaucomatous and normal eyes. Invest Ophthalmol Vis Sci 1994;35:1848.

14 Tateyama H, Hino J, Minaimino N, et al. Characterization of immunoreactive brain natriuretic peptide in human cardiac atrium. Biochem Biophys Res Comm 1990;166:1080-7.

15 Burch M, Lincoln C, Carter N, et al. Acute sternal opening after cardiac surgery in children: effect on plasma atrial natriuretic peptide. $\mathcal{F}$ Cardiovasc Surg 1991;32:246-50.

16 Ationu A, Singer DRJ, Smith A, Elliott M, et al. Studies of cardiopulmonary bypass in children:implications for the regulation of brain natriuretic peptide. Cardiovasc Res 1993:s27:1538-41.

17 Sonntag JR, Brindley GO, Shields MB. Effect of timolol therapy on outflow facility. Invest Ophthalmol Vis Sci 1978 . 17:293-6.
18 Calla S, Gupta A, Sen, Garg IP. Comparison of effects of etomidate and thiopentone on intraocular pressure. $\mathrm{Br} F$ Anaesth 1987;59:437-9.

19 Cunningham AJ, Barry P. Intraocular pressure-physiology and implications for anaesthetic management. Can Anaesth Soc F 1986;33:195-208.

20 Mirakhur RK, Eliott P, Shepherd WFI, et al. Intraocular pressure changes during induction of anaesthesia and tracheal intubation: a comparison of thiopentone and propofol followed by vecuronium. Anaesthesia $1988 ; 43$ Suppl: pofol 7 .

21 Meyer D, Hamilton RC, Loken RG, et al. Effect of combined peribulbar and retrobulbar injection of large volumes of of anaesthetic agents on the intraocular pressure. Can f Ophthalmol 1992;27:230-2.

22 Stevens J, Giubilei M, Lanigan L, et al. Sub-Tenon, retrobulbar and peribulbar local anaesthesia: the effect upon intraocular pressure. Eur f Implant Ref Surgery 1993;5:258 .

23 O'Donoghue E, Batterbury M, Lavy T. Effect on intraocular pressure of local anaesthesia in eyes undergoing intraocular surgery. Br f Ophthalmol 1994;78:605-7.

24 Fernandez-Durango R, Nunez DJ, Brown MJ. Messenger RNAs encoding the natriuretic peptides and their receptors are expressed in the eye. Exp Eye Res 1995;61:723-9.

25 Krause U, Raunio V. Proteins of the normal human aqueous humour. Ophthalmologica 1969;159:178-85.

26 Dernouchamps JP. The proteins of the aqueous humour. Doc Ophthalmol 1982;53:193-248.

27 Nathanson J. Atriopeptin-activated guanylate cyclase in the anterior segment. Identification, localization and effects of atriopeptins on IOP. Invest Ophthamol Vis Sci 1987;28: 1357-64.

28 Wolfensberger TJ, Holz FG, Ationu A, et al. Natriuretic peptides and their receptors in human neural retina and retinal pigment epithelium. Ger f Ophthalmol 1994:3:24852. 